\title{
Tissue Transglutaminase IgM Antibody Measurement
}

National Cancer Institute

\section{Source}

National Cancer Institute. Tissue Transglutaminase IgM Antibody Measurement. NCI

Thesaurus. Code C147442.

The determination of the amount of tissue transglutaminase $\lg \mathrm{M}$ antibody present in a sample. 